\title{
W drodze do miejsc świętych - krytyka chrześcijańskiego pielgrzymowania na przełomie wieków jako inspiracja dla duszpasterstwa pielgrzymkowego
}

\author{
On the way to holy places - old and new criticism \\ of pilgrimage in the Christian tradition as inspiration \\ for the pastoral accompaniment of pilgrims
}

\begin{abstract}
Abstact: According to the religious phenomenon of pilgrimage in the monotheistic religions the author references to the criticism of pilgrimage in the early church fathers. Their shifting of the focal point from the extern to an interior pilgrimage can also be considered today in the Catechism of the Catholic Church. From there consequences concerning the motivation to Christian pilgrimage, the locus sacer, the transitus from extern to interior pilgrimage as well as ecumenical aspects are discussed for the pastoral accompaniment of pilgrims.
\end{abstract}

Keywords: pilgrimage, pilgrim, monotheistic religions, church fathers, Catechism of the Catholic Church, spirituality, pastoral ministry, ecumenism

\section{Pielgrzymowanie - fenomen trzech wielkich religii monoteistycznych}

Ludzie różnych wieków i narodów nieustannie wybierali się w drogę do miejsc świętych. W niektórych religiach świata pielgrzymowanie do głównych sanktuariów jest religijnym obowiązkiem. Zwróćmy się najpierw ku judaizmowi. W Izraelu 
pielgrzymowanie do świątyni jerozolimskiej należało, już wkrótce po jej wybudowaniu, do podstawowych aktów pobożności narodu wybranego (por. $1 \mathrm{Krl} 8$, 9,25). Pielgrzymowanie tak mocno wpisało się w mentalność Izraelitów, że Jeroboam (931-910 p.n.e.) - nowy król Królestwa Północnego - wykorzystał je, aby odwieść naród wybrany od prawdziwego Boga (por. $1 \mathrm{Krl} \mathrm{12,} \mathrm{26-33).}$ Poprzez ustanowienie nowych miejsc kultu chciał przeszkodzić Izraelowi w tradycji pielgrzymowania do świętego miasta. Obawiał się bowiem, że Królestwo Północne poprzez zgromadzenia wokół Jahwe na Syjonie w Jerozolimie, może zwrócić się z powrotem ku Roboamowi - królowi Judy (931-914 p.n.e.). Powyższe obawy Jeroboama zaowocowały tym, że ustawil on dwa złote cielce $w$ dwóch nowo ogłoszonych miejscach pielgrzymkowych: Bet El i Dan. Aby móc sprawować kult, ustanowił sam siebie kapłanem dla pielgrzymującego ludu (por. $1 \mathrm{Krl} 12$ ), jak też wbrew tradycji powołał kapłanów spośród pokoleń nie należących do rodu lewitów oraz wprowadził święto pielgrzymowania (por. $1 \mathrm{Krl}$ 12,32-33). W ten sposób w pielgrzymkowym kalendarzu Izraela znalazły się pogańskie święta nowych sanktuariów.

W celu ożywienia pielgrzymowania sam Jeroboam wyruszył w drogę do ustanowionych przez siebie miejsc pielgrzymkowych i złożył tam ofiarę, dając $w$ ten sposób przykład swojemu ludowi (1 Krl 12,33). W Księdze Królewskiej czyn Jeroboama został ostatecznie określony jako grzech, (1 Krl 13,34) dlatego, że król wędrował nie do miejsc kultu Boga żywego, lecz do bożków, przy udziale fałszywych kapłanów. Pielgrzymowanie zaś było w Izraelu działaniem gromadzącym wszystkie pokolenia z Północy i Południa we wspólnej drodze do świątyni Jahwe, ruchem jednoczącym cały lud i w ten sposób przywracającym jedność rozbitego królestwa Dawida. Do tego zaś Jeroboam nie chciał dopuścić.

Nie tylko na podstawie tej jednej historii opisanej w Księdze Królewskiej można wnioskować, że w Starym Testamencie pielgrzymowanie posiadało jednoczącą naród siłę o głębokim podtekście politycznym. Mogliśmy to prześledzić na przykładzie obaw króla Jeroboama przed pielgrzymowaniem do Jerozolimy i jej potencjałem jednoczącym dwie części narodu izraelskiego, w bolesny sposób rozbitego na Królestwo Izraela i Królestwo Judy Identyfikacyjna siła pielgrzymowania została na nowo odkryta w okresie po zburzeniu świątyni jerozolimskiej, a wraz z tym zniszczeniu duchowego centrum i miejsca wspólnej modlitwy (Pasquato 1989). Dużym problemem dla rabinów stała się wówczas troska o jedność narodu żydowskiego, gdyż zniknął jego narodowy i religijny symbol na Syjonie (Manns 1989). Po katastrofie babilońskiego wygnania, pielgrzymowanie do Jerozolimy 
stało się nawet obowiązkiem religijnym, aby przeciwdziałać tendencjom niszczącym jedność narodu oraz aby gromadzić lud w jednej wierze i wspólnym kulcie (Kötting 1950). Poprzestańmy na powyższych uwagach odnośnie Izraelitów i ich rozumieniu znaczenia pielgrzymowania i przejdźmy do islamu.

W islamie haddasch - czyli pielgrzymowanie do Mekki - należy do pięciu filarów wiary muzułmańskiej. Przypisano mu także specjalny czas i ryty ofiarne. Każdy wierzący muzułmanin - mężczyzna i kobieta - powinien przynajmniej raz w życiu pielgrzymować do Mekki. W Koranie jest to zapisane następująco: „Na ludziach ciąży obowiązek względem Boga - na tych, którzy maja ku temu środki - odprawienia pielgrzymki do tego Domu” (Koran1986, Sura 3,97:75). Zazwyczaj ponad dwa miliony wierzących corocznie wyruszają z pielgrzymką do Mekki, aby spełnić swój religijny obowiązek ${ }^{1}$.

W związku z tym może być zadziwiające, że w chrześcijaństwie - biorąc pod uwage tradycje obydwu przedstawionych wcześniej religii monoteistycznych nie istnieje obowiązek pielgrzymowania. Nie wchodzi ono ani w skład wskazań przekazanych przez Jezusa, ani nie należy do przykazań Kościoła czy też do specjalnych religijnych obowiązków chrześcijan ${ }^{2}$. Z tego względu nie przywiązuje się zbytniej wagi do faktu, że rodzina Jezusa, jako przykładni Żydzi, pielęgnowała tradycje pielgrzymowania do Jerozolimy (por. Łk 2, 22; 41-42). Także sam Jezus wraz ze swoimi uczniami wielokrotnie wędrował do świętego miasta ${ }^{3}$ a Marek Ewangelista w swojej Ewangelii opisał bieg wydarzeń z życia Jezusa jako długą pielgrzymkę do Jerozolimy. W książeczce O naśladowaniu Chrystusa, napisanej w okresie późnego średniowiecza przez Tomasza a Kempis, mającej duży wpływ na chrześcijańską duchowość, znajduje się stanowcze ostrzeżenie przed zbyt

1 Por. http://www.tagesschau.de/ausland/hadsch-mekka100.html (15.02.2014).

2 Zostało to przedstawione także jako główny argument teologiczny w krytyce pielgrzymowania przez Grzegorza z Nyssy. Por. tutaj opracowanie Berharda Köttinga, 1962, Gregor von Nyssa's Wallfahrtskritik, „Studia Patristica”, 5 (,Texte und Untersuchungen zur Geschichte der altchristlichen Literatur" 80), s. 360-367, tu s. 362-363.

3 W Katechizmie Kościoła Katolickiego czytamy w odniesieniu do Jezusa: „Podobnie jak wcześniejsi prorocy Jezus okazywał bardzo głęboki szacunek dla Świątyni Jerozolimskiej. Został w niej ofiarowany przez Józefa i Maryję w czterdziestym dniu po narodzeniu (por. Łk 2,22-39). W wieku dwunastu lat decyduje się na pozostanie w Świątyni w celu przypomnienia swoim rodzicom, że powinien być w sprawach Ojca (por. Łk 2, 46-49). W czasie swego życia ukrytego udawał się do niej co roku przynajmniej na święto Paschy (Łk 2, 41), samą Jego misję publiczną wyznaczał rytm pielgrzymek do Jerozolimy na wielkie święta żydowskie" (por. J 2,13-14; 5,1; 7,2, 10. 14; $8,2 ; 10,22-23)$ (n. 583). 
częstymi pielgrzymkami: „Choroba mało kogo poprawia, jak mało kogo uświęca pielgrzymka” (Kempis 1980, Księga I, rozdział XXIII: 9). Krytyczne spojrzenie na pielgrzymowanie w duchowości chrześcijańskiej, jakby się zdawało w pierwszym momencie, stoi w sprzeczności z przykładem danym nam przez samego Jezusa, wyraża się dystansem wobec tej praktyki, którego przykładem jest chociażby wypowiedź Tomasza a Kempis. Jawi się też jako ostre przeciwieństwo wobec dynamicznego rozwoju zjawiska pielgrzymowania w ostatnich latach, który jest oznaką swoistego nowego przełomu religijnego.

Dlaczego zatem w chrześcijaństwie doszło do krytyki pielgrzymowania? Czym jest ona uzasadniona i jakie płyną z niej wskazania bądź konieczne korekty dotyczące duszpasterstwa osób zmierzających do świętych miejsc, których liczba nieustannie wzrasta? Przyglądnijmy się najpierw negatywnym tendencjom w podejściu do zjawiska pielgrzymowania w pierwotnym Kościele, a następnie przejdźmy do ujęcia tego zagadnienia w Katechizmie Kościoła Katolickiego (2012), oficjalnym dokumencie kościelnym po Soborze Watykańskim II, zawierającym szczególne pastoralne uwagi na interesujący temat. Stąd można wyprowadzić ważne wnioski dla duszpasterstwa pielgrzymkowego.

\section{Teologiczne źródła krytyki pielgrzymowania w pierwszych wiekach chrześcijaństwa}

Pierwsza wyraźna krytyka pielgrzymowania pochodzi od Grzegorza z Nyssy (IV w.). Sam Grzegorz jako pielgrzym udał się do Ziemi Świętej, świętego miasta Jeruzalem i innych świętych miejsc, o czym nie bez zachwytu pisał w jednym ze swoich listów, wspominając, jak ta droga pielgrzymowania na nowo roznieciła jego wiarę (Kötting 1950, Pasquali 1959). Jednakże w innym liście podjął już wyraźną krytykę pielgrzymowania. Wyraża w nim niepokój o stan moralny schronisk dla pielgrzymów, ale także o niemoralne zachowania w trakcie drogi, które wiążą się ze szkodami duchowymi. Brakuje mu także wyraźnego wskazania od Pana, by podejmować tego typu dzieła. Pielgrzymowanie bowiem nie znajduje się ani wśród żadnych nakazów Chrystusa, ani w Jego błogosławieństwach. „Dlaczego zatem brać na siebie ten ciężar i trud pielgrzymki, jeśli nie uświęca on [człowieka]?” - pyta Grzegorz z Nyssy (Kötting 1950: 363)4. Gdyby też brać pod uwagę same

${ }^{4}$ Cytat w thumaczeniu ks. M. Ostrowskiego. 
sanktuaria, to nie jest w nich bardziej cieleśnie obecny Jezus, ani bardziej działa w nich Duch Święty - widoczny przynajmniej poprzez zmianę życia tam przybywających - niż w innych Bożych domach Kapadocji (Kötting 1950, Rigi 1989).

W naszych analizach przejdźmy teraz do literatury wczesnochrześcijańskiej, by przekonać się, że pielgrzymowanie od samego początku chrześcijaństwa nie odgrywało istotnej roli (Rigi 1989). W nowotestamentowej i wczesnopatrystycznej literaturze bycie $\mathrm{w}$ drodze chrześcijan wiązało się bardziej z prawdami zawartymi w Ewangelii niż z fizycznym pielgrzymowaniem do świętych miejsc ${ }^{5}$. Cechą charakterystyczną pierwszych chrześcijan z pewnością nie była ich pielgrzymkowa aktywność. Mimo to oni sami byli określani jako członkowie wspólnoty zwanej droga, a stąd też ludzie, których egzystencja nacechowana była byciem $w$ drodze. Z takim stwierdzeniem spotykamy się już w Dziejach Apostolskich, gdzie chrześcijan określa się jako zwolenników „nowej drogi” (Dz 9,2; 19,9; 22,4; 24,4) oraz „będącymi na drodze Pana” (Dz 18,25). Ich egzystencjalna droga i bycie $w$ drodze zastępowały fizyczną pielgrzymkę do głównego sanktuarium w Jerozolimie. Św. Paweł w Pierwszym liście do Koryntian, świadomie nawiązując do tradycji pielgrzymowania do świątyni w Jerozolimie, dokonuje egzystencjalnego porównania: „Czyż nie wiecie, że jesteście świątynią Boga i że Duch Boży w was mieszka? (...). Jeżeli ktoś niszczy świątynię Boga, tego i Bóg zniweczy, ponieważ jest święta. Wy właśnie jesteście tą świątynią” (1Kor 3, 16-17) ${ }^{6}$.

5 Jako wyjątek jawi się tutaj bp Meliton z Sardes, jeden z pierwszych który takie wymagania postawił pielgrzymom. Według Euzebiusza, w połowie drugiego stulecia Meliton sam obszedł miasta Ziemi Świętej, gdyż na własne oczy chciał zobaczyć to, co zawiera się w Piśmie Świętym a o czym sam przepowiadał i czym chciał się sam napełnić. Por. Eusebius von Caesarea, HE IV, 16,14.

6 Po motyw świątyni jerozolimskiej sięgnął w swoim kazaniu także papież Franciszek: „Duch Święty mówi także do nas dzisiaj słowami św. Pawła: "Czy nie wiecie, że jesteście świątynią Boga (...) Jeżeli ktoś niszczy świątynię Boga, tego i Bóg zniweczy, ponieważ jest święta. Wy właśnie jesteście tą świątynią" (1 Kor 3,1617). W tej świątyni, którą my jesteśmy, świętowana jest liturgia życia: dobra i służby innym, jednym słowem liturgia miłości. Świątynia ta jest profanowana, jeżeli lekceważymy obowiązki względem bliźnich. Jeżeli w naszych sercach najmniejszy $z$ braci znajduje swoje miejsce, tam również sam Bóg jest obecny, tam znajduje miejsce dla siebie. Serce bez miłości jest jak sprofanowany Kościół, który zaniedbuje służbę Bożą i określany jest przez coś innego" (Franziskus, 2014, Dem evangelium dienen und der Kirche helfen, „L'Osservatore Romano” (Deutsche Auflage), nr. 9 (28.02.2014), s. 1). 
Pielgrzymowanie do świętych miejsc, w których Jezus żył, cierpiał i zmartwychwstał, jest w istocie stosunkowo późnym zjawiskiem, które w dużej mierze zaczęło się kształtować dopiero po Edykcie mediolańskim w 313 r. Powodami ku temu były: niepewność jaką niosły ze sobą podróże chrześcijan przed okresem konstantyńskiego pokoju, trudności komunikacyjne, ciągle na nowo wybuchające prześladowania chrześcijan i związany z nimi brak ich ochrony (Pasquato 1989). Za przykład pątniczki tamtejszych czasów uchodzi Egeria z jej bardzo znanym opisem pielgrzymki do Ziemi Świętej (Kötting 1950, Egeria 1995).

Jednakże już od początku chrześcijańska świadomość została zdominowana przez nowotestamentowy motyw egzystencjalnej drogi bez konieczności wyruszania w drogę do widzialnych sanktuariów. Po ten wczesnochrześcijański motyw w swojej refleksji teologicznej sięgał św. Augustyn w polemice z religijnością Starego Testamentu oraz religiami pogańskimi. Doskonale wydobył to Joseph Ratzinger, komentując świętego Ojca Kościoła. W swej argumentacji Augustyn opiera się na porównaniu pielgrzymki do świątyni jerozolimskiej i do wędrówki ku pogańskim miejscom kultu: „Pogaństwo i Stary Testament są wprawdzie w swoich podstawach różne: jedno jest służbą bożkom, drugie nakierowane jest na służbę Bogu żywemu. Ale w jednym są takie same, mianowicie w służbie Bożej wyrażającej się na zewnątrz (mundus sensibilis). Obydwa wychwalają bóstwo przez zewnętrzne, widzialne budowle i przez zewnętrzne czyny ludzkie. Obydwie religie, czy to przez wiele świątyń, czy to przez jedną świątynię znajdują swój ostateczny sposób wyrazu. Bóg jednak żyje, jakby to można wyrazić, bytuje w całkiem innym wymiarze, mianowicie w mundus intelligibilis. Tak więc także cześć oddawana Bogu w świątyni, tak jak kult odprawiany w Starym Testamencie (jak i cały Stary Testament) są tylko cieniem i zapowiedzią prawdziwego kultu. (...) Odpowiednikiem rzeczywistości pogańskiej świątyni po chrześcijańskiej stronie nie jest Dom Boży, ale jesteśmy nim my sami, to jest wspólnota wierzących, Lud Boży. Następuje tu pewne odwrócenie porządku. Miejscem zebrania Bożego Ludu w chrześcijaństwie, i to jest znaczące, jest on sam" (Ratzinger 1992: 173-174). W związku z tym J. Ratzinger formułuje następujący wniosek: „Augustyn odrzuca świątynię, która przynależy do mundus sensibilis, do czystej widzialności. Ale na tym miejscu nie wymaga on jedynie czysto duchowego, wewnętrznego kultu, lecz prawdziwej świątyni dopatruje się w chrześcijańskiej wspólnocie, która staje się widzialna w celebracji eucharystycznej" (Ratzinger 1992: 175). 
Być może za tym ostrym rozróżnieniem Augustyna na świątynię zewnętrzną (pogańsko/żydowską) i wewnętrzną (chrześcijańską) stoi wiedza na temat ekscesów, jakie miały miejsce w trakcie pielgrzymek do Rzymu, kiedy pielgrzymi obok pobożnych modlitw - oddawali się światowym radościom. W liście z 395 r. Augustyn krytykuje nieobyczajne święta i biesiady towarzyszące zdążającym do Rzymu, zaczerpnięte z afrykańskich zwyczajów, których jednak nie można było ukrócić (Kötting 1950). To przekonanie Augustyna o nasyconym pogaństwem powierzchownym byciu $w$ drodze do Domu Bożego, kontrastuje z wyrażonym w jego wczesnych pismach poglądem na temat świątyni Bożej we wnętrzu człowieka: „Sensem zewnętrznego kościelnego kultu jest jedynie to, by przypomnieć człowiekowi i poprowadzić go do wewnętrznego kultu Bożego. Sprawowany jest on nie ze względu na Boga i nie ma zatem żadnego religijnego sensu, ale jest sprawowany tylko ze względu na człowieka. Ma on sens, jeśli chce wskazać daleko poza siebie na jedynie ważny kult serca" (Ratzinger 1992: 37).

Augustyn rozumie zatem wewnętrzną świątynię jako zamieszkanie Boga, jako „duchowe bycie w sobie człowieka”, nie zaś jako zewnętrzną, przestrzennie pojętą obecność. Dlatego dochodzi do sformułowania następującej zasady: „do Boga możemy iść nie stopami, ale sercem" (Augustinus 1917: 115). W opisie wewnętrznego pielgrzymowania Augustyn używa słów, które wyrażają dynamikę wyruszania w drogę, pójścia do przodu, ale także pobłądzenia na szlakach (Augustinus 1914). Przy całym wewnętrznym ujęciu przez Augustyna kwestii pielgrzymowania, w jego koncepcji na ten temat staje się widoczna dynamika bycia w drodze. Świadczą o tym używane przez niego określenia: iść, pielgrzymować. Odnoszą się one do człowieka wędrującego ku Bogu, nawet wówczas, gdy odbywa on swą pielgrzymkę w niewłaściwy sposób. Wyraża tę prawdę na podstawie osobistego doświadczenia: „Dopóki w mej pielgrzymce jestem jeszcze daleko od Ciebie, bardziej jestem siebie samego niżeli Ciebie świadom" (Augustyn 1987: 222).

Z dotychczasowych analiz jest tylko mały krok do refleksji nad kwestią pielgrzymującego Kościoła. Nie tylko pojedynczy chrześcijanin bytuje $w$ drodze. Pielgrzymujący jest także cały Kościół, Lud Boży, Ciało Chrystusa7. Motyw pielgrzymującego Ludu Bożego pojawia się pod wpływem Listu do Hebrajczyków,

7 Eklezjologiczny kontekst tego sformułowania por. J. Ratzinger, 1963, Wesen und Grenzen der Kirche, [w:] K. Forster (red.), Das Zweite Vatikanische Konzil (SBKAB 24), Würzburg, s. 47-68; również jako: Der Kirchenbegriff und die Frage nach der Gliedschaft in der Kirche, 1969, [w:] Das neue Volk Gottes. Entwürfe zur Ekklesiologie, Düsseldorf, s. 90-104. 
co znajduje odzwierciedlenie także u Augustyna. W Liście do Hebrajczyków Kościół został ukazany jako Lud Boży (Hbr 4,9) w jego ziemskiej wędrówce do Wiecznej Ojczyzny (Müller 1995), wedle głębokiego przekonania wiary, że: „Nie mamy przecież tutaj trwałego miasta, ale dążymy do tego, które nas czeka w przyszłości" (Hbr 13,14) ${ }^{8}$.

W swojej pielgrzymkowej eklezjologii, obok problemu bycia w drodze Kościoła, mającego eschatologiczny charakter, Augustyn podjął także temat niebezpieczeństw na szlaku pielgrzymki. W jego koncepcji wszelkie zło, wrogość bądź przeciwności przyczyniają się jednak do umocnienia pielgrzymującego Kościoła i utwierdzenia go w cierpliwości, mądrości i życzliwości (Augustinus 1916).

Podsumowując dotychczasowe refleksje zawarte w krótkim zarysie problemu od czasów pierwotnego Kościoła po dzień dzisiejszy, można stwierdzić, że krytyka pielgrzymowania $\mathrm{w}$ aspekcie jedynie zewnętrznego bycia $w$ drodze odnosi się tak do kwestii ziemskiej egzystencji człowieka rozumianej jako bycie $w$ drodze do Boga, jak też do Ludu Bożego jako całości. Są oni jednakowo w drodze do wiecznego miasta Jeruzalem. Przesunięcie głównego akcentu pielgrzymowania z zewnętrznego bycia w drodze do świętych miejsc ku duchowemu byciu w drodze wiary ku osobie Jezusa Chrystusa i ku eschatologicznemu Miastu, staje się zasadniczym teologicznym punktem odniesienia dla krytyki pielgrzymowania przeprowadzanej przez Ojców Kościoła w pierwszych wiekach chrześcijaństwa.

\section{Krytyka pielgrzymowania - korekta i wartości - w Katechizmie Kościoła Katolickiego. Krótka analiza wypowiedzi na temat pielgrzymek, pielgrzymowania i pielgrzymów}

Od spojrzenia starożytnego Kościoła przejdźmy teraz do Katechizmu Kościoła Katolickiego (1992). Podczas gdy w starszych katechizmach pielgrzymowanie było zalecane jako droga pogłębiania wiary, to w nowym odgrywa ono drugorzędną rolę. Po temat pielgrzymowania sięgnięto pierwszy raz, ubocznie, przy okazji drugiej

8 Motyw pielgrzymującego Kościoła w Hbr 13,14 por. przykładowo Augustinus, 1925, Enchiridion, d.h. Handbüchlein für den Laurentius oder Buch vom Glauben, von der Hoffnung und von der Liebe, [w:] Des heiligen Kirchenvaters Aurelius Augustinus ausgewählte Schriften. Aus dem Lateinischen übersetzt, BKV I/ 49), Kempten-München, s. 444. 
części rozważań o sakramencie pokuty ${ }^{9}$. Następnie podjęto go w ramach omawiania kwestii pobożności ludowej ${ }^{10}$. Dalej temat pielgrzymowania został wymieniony w kontekście dobrowolnej ofiary, ślubowania i obietnicy, które może i powinien składać chrześcijanin oraz jego osobistej pobożności ${ }^{11}$. Ważną wskazówkę dla teologicznego uzasadnienia pielgrzymowania, mając na uwadze wczesnochrześcijański dystans w tej materii, znajdujemy w czwartym rozdziale Katechizmu. Czytamy w nim: „Świątynia miała być dla Ludu Bożego miejscem jego wychowania do modlitwy. Pielgrzymki, święta, dary ofiarne, ofiara wieczorna, kadzidła, chleby pokładne - wszystkie te znaki świętości i chwały Boga Najwyższego, a bardzo bliskiego, były wezwaniami i drogami modlitwy. Rytualizm prowadził jednak często lud do zbyt zewnętrznego kultu. Potrzeba było wychowania wiary i nawrócenia serca. Było to zadaniem proroków zarówno przed wygnaniem, jak i po nim" (KKK 2581). Niebezpieczeństwo sprowadzenia pielgrzymowania do zewnętrznie praktykowanego kultu, mobilizowało proroków do podjęcia się misji wychowania ludu do prawdziwej, wewnętrznej wiary, wyrażanej nawróceniem serca.

W krytyce pielgrzymowania podjętej w Katechizmie odzwierciedla się wątek zaczerpnięty z myśli św. Augustyna. By ugruntować swój punkt widzenia wobec wypaczonych form pielgrzymowania Katechizm odnosi się do obrazów zaczerpniętych ze Starego Testamentu. Podejmuje krytykę w świetle obowiązku pielgrzymowania przyjętego w Izraelu. Jedyna pozytywna wypowiedź dotycząca

9 „Okresy i dni pokuty w ciągu roku liturgicznego (Okres Wielkiego Postu, każdy piątek jako wspomnienie śmierci Pana) są w Kościele specjalnym czasem praktyki pokutnej. Okresy te są szczególnie odpowiednie dla ćwiczeń duchowych, liturgii pokutnej, pielgrzymek o charakterze pokutnym, dobrowolnych wyrzeczeń, jak post i jałmużna, braterskiego dzielenia się z innymi (dzieła charytatywne i misyjne)" (Katechizm Kościoła Katolickiego dalej KKK 1438). Z kolei odnośnie pytania o generalną absolucję podczas pielgrzymek por. KKK 1483 oraz odnośnie podziału Psalmów, wśród których niektóre są nazywane pielgrzymimi por 2588.

10 „Poza liturgią sakramentów i sakramentaliów katecheza powinna brać pod uwage formy pobożności wiernych i religijności ludowej. Zmysł religijny ludu chrześcijańskiego zawsze znajdował wyraz w różnorodnych formach pobożności, które otaczały życie sakramentalne Kościoła. Są to: cześć oddawana relikwiom, nawiedzanie sanktuariów, pielgrzymki, procesje, droga krzyżowa, tańce religijne, różaniec, medaliki itp.” (KKK 1674).

11 „W wielu sytuacjach chrześcijanin jest wzywany do składania przyrzeczeń Bogu. Zawierają je chrzest, bierzmowanie, małżeństwo i święcenia. Chrześcijanin kierując się pobożnością, może przyrzec Bogu określony czyn, modlitwę, jałmużnę, pielgrzymkę itd. Wierność przyrzeczeniom złożonym Bogu jest przejawem szacunku należnego Boskiemu Majestatowi i miłości wobec wiernego Boga" (KKK 2101). 
pielgrzymowania znajduje się w związku z pytaniem o odpowiednią przestrzeń dla modlitwy. Pod numerem 2691 zostały wyeksponowane pastoralne i duchowe wartości pielgrzymowania oraz ich eschatologiczne uzasadnienie. Czytamy tam: „Pielgrzymki przypominają naszą wędrówkę na ziemi ku niebu. Tradycyjnie już są one czasem intensywnej odnowy modlitwy. Dla pielgrzymów poszukujących właściwych im żywych źródeł, sanktuaria są wyjątkowymi miejscami przeżywania «jako Kościół» modlitwy chrześcijańskiej” (KKK 2691). Mocnym potwierdzeniem tej wypowiedzi jest zapis 2696, w którym czytamy: „miejscami najbardziej sprzyjającymi modlitwie są: oratoria - osobiste lub rodzinne, klasztory, sanktuaria pielgrzymkowe. Tu Katechizm, jednym tchem, doprecyzowuje, że to przede wszystkim kościół (...) jest właściwym miejscem modlitwy liturgicznej dla wspólnoty parafialnej oraz uprzywilejowanym miejscem adoracji eucharystycznej" (KKK 2696).

O powrocie pielgrzymów - którzy wybrali się, by nawiedzić oddalone sanktuaria - do miejscowego kościoła, będącego podstawową wspólnotą wiary i miejscem celebracji liturgii, wspomina Grzegorz z Nyssy w swojej krytyce pielgrzymowania. "Porzuć swoje ciało i pielgrzymuj do Pana, zamiast z Kapadocji do Palestyny" (Kötting 1962: 365). Zdanie to może być zrozumiałe w kontekście pastoralnym, gdyż intensywna aktywność pielgrzymkowa niosła ze sobą zagrożenie migracji członków parafii, przez co mogło dojść do zniszczenia jedności i identyfikacji z Kościołem lokalnym.

Jednakże Katechizm Kościoła Katolickiego uznaje, że święte miejsca są niezbędne dla gromadzenia Ludu Bożego. W ten sposób dobitniej ukazują one cel ziemskiej egzystencji człowieka, noszącej pielgrzymi charakter. Czytamy w nim: „W warunkach życia na ziemi Kościół potrzebuje miejsc, w których mogłaby gromadzić się wspólnota wiernych. Są nimi nasze widzialne świątynie, święte miejsca, będące obrazami Miasta Świętego, niebieskiego Jeruzalem, do którego pielgrzymujemy” (KKK 1198). Funkcją świętego miejsca, ucieleśnieniem którego dla Izraelitów była jeszcze świątynia jerozolimska - ma być teraz duchowe zgromadzenie wierzących na modlitwie. Prawdziwą świątynią, ku której zmierzają chrześcijanie jest sam Chrystus oraz oni sami - jako żywe świątynie Ducha Świętego ${ }^{12}$. Katechizm mocno zaakcentował tę prawdę, powołując się na tradycję augustyńską (KKK 1199).

$\overline{12}$ KKK 1199, obok objaśnienia publicznego kultu, który gromadzi nowy Lud Boży, dodaje: „Te świątynie są również miejscami skupienia i modlitwy osobistej”. 
W Katechizmie w związku z tematem pielgrzymowania bardzo mocno rzuca się w oczy, powtórzenie za Soborem Watykańskim II, prawdy o Kościele pielgrzymującym, nieustannie będącym $\mathrm{w}$ drodze do wiecznej radości ${ }^{13}$. Sobór i Katechizm, odnosząc się do interpretacji Ojców Kościoła, wyprowadzają obraz pielgrzymującego Kościoła z wędrówki narodu wybranego przez pustynię do Ziemi Obiecanej, opisanej w Księdze Wyjścia (Danielou 1950). W jaki sposób obraz ten funkcjonuje na kartach Katechizmu?

Już we wstępie do Katechizmu znajdujemy zdanie, że „Kościół Boży, będący Ciałem Chrystusa, pielgrzymujący ku niegasnącej światłości Królestwa”14, jest powołany przez Ducha Świętego do ustawicznej odnowy. Tenże motyw pielgrzymującego Kościoła staje się złotą nicią przenikającą różne tematy zawarte w Katechizmie, poczynając od tego, że jest on sam świętą spuścizną pozostawioną przez Boże Słowo (KKK 97), poprzez bycie w świecie jako pielgrzym, aż po próby, jakie Kościół w trakcie swej pielgrzymiej drogi musi znosić ${ }^{15}$, by móc

${ }^{13}$ W KKK mowa o pielgrzymującym Ludzie Bożym, o pielgrzymującym Kościele i o Chrystusie jako pielgrzymie na ziemi wybrzmiewa w zamieszczonej tu Konstytucji o Kościele „Lumen Gentium“ (dalej KK) 14 razy, por. KK 6,7, 8, 14, 21, 48, 49, 50, 58 i raz w podtytule do rozdziału VII.

14 Jan Paweł II, Konstytucja Apostolska „Fidei depositum”, ogłoszona z okazji publikacji Katechizmu Kościoła katolickiego, 11 października 1992 r.

15 „Przed przyjściem Chrystusa Kościół ma przejść przez końcową próbę, która zachwieje wiarą wielu wierzących. Prześladowanie, które towarzyszy jego pielgrzymce przez ziemię , odsłoni "tajemnicę bezbożności" pod postacią oszukańczej religii, dającej ludziom pozorne rozwiązanie ich problemów za cenę odstępstwa od prawdy. Największym oszustwem religijnym jest oszustwo Antychrysta, czyli oszustwo pseudomesjanizmu, w którym człowiek uwielbia samego siebie zamiast Boga i Jego Mesjasza, który przyszedł w ciele” (KKK 675); podobnie w odniesieniu do wiary: „Teraz jednak "według wiary, a nie dzięki widzeniu postępujemy" (2 Kor 5,7) i poznajemy Boga "jakby w zwierciadle, niejasno... po części" (1 Kor 13,12). Wiara, która jest pełna światła dzięki Temu, w którego wierzymy, często jest przeżywana w ciemności. Może być wystawiona na próbę. Świat, w którym żyjemy, bardzo często wydaje się daleki od tego, o czym zapewnia nas wiara. Doświadczenia zła, cierpienia, niesprawiedliwości i śmierci wydaja sie zaprzeczać Dobrej Nowinie; mogą one zachwiać wiarą i stać się dla niej pokusa”” (KKK 164); dalej: „W swojej pielgrzymce Kościół doświadcza jednak "rozbieżności między nauką, którą głosi, a ludzką słabością tych, którym powierzona jest Ewangelia". Jedynie idąc drogą "ustawicznej pokuty i odnowy" (KK 8) oraz "kkrocząc wąską drogą Krzyża", Lud Boży może rozszerzać Królestwo Chrystusa . Istotnie, «jak Chrystus dokonał dzieła Odkupienia w ubóstwie i wśród prześladowań, tak i Kościół powołany jest do wejścia na tę sama drogę, by udzielać ludziom owoców zbawienia"” (KK 8) (KKK 853). 
wreszcie osiągnąć ostateczny cel swojej pielgrzymki ${ }^{16}$. Na tej pielgrzymiej drodze Kościół posiada swoich orędowników i wzory w wierze w aniołach i świętych ${ }^{17}$, jak Abrahama i Maryję ${ }^{18}$, przy czym Matka Boża - jako towarzyszka i przewodniczka drogi - odgrywa wyjątkową rolę. Dalej Katechizm wskazuje na codzienny chleb pielgrzymów, jakim jest Eucharystia ${ }^{19}$. W liturgii Kościół pielgrzymujący

16 „Kościół osiągnie swoje wypełnienie tylko w chwale nieba” (KK 4), w chwili chwalebnego powrotu Pana. Do tego dnia "Kościół kontynuuje swoją pielgrzymkę wśród prześladowań świata i pocieszeń Boga". Tu na ziemi czuje się na wygnaniu, z daleka od Pana, "tęskni do Królestwa w pełni dokonanego... i pragnie połączenia się z Królem swoim w chwale". Wypełnienie Kościoła w chwale a za jego pośrednictwem wypełnienie świata - dokona się jedynie przez przejście ciężkich prób. Tylko wtedy "wszyscy sprawiedliwi, poczynając od Adama, od Abla sprawiedliwego aż po ostatniego wybranego, zostaną zgromadzeni w Kościele powszechnym u Ojca” (KK 5) (KKK769).

${ }^{17}$ „W swojej modlitwie Kościół pielgrzymujący jest złączony z modlitwą świętych, których usilnie prosi o wstawiennictwo” (KKK 2692); „Kościół czci aniołów, którzy pomagają mu w jego ziemskiej pielgrzymce i opiekują się wszystkimi ludźmi" (KKK 352).

${ }^{18}$ List do Hebrajczyków, głosząc wielką pochwałę wiary przodków, podkreśla w sposób szczególny wiarę Abrahama: „Przez wiarę ten, którego nazwano Abrahamem, usłuchał (okazał posłuszeństwo) wezwania Bożego, by wyruszyć do ziemi, którą miał objąć w posiadanie. Wyszedł, nie wiedząc, dokąd idzie" (Hbr 11,8). Przez wiare żył jak "cudzoziemiec" i "pielgrzym" w Ziemi Obiecanej. Przez wiare Sara otrzymała moc poczęcia syna obietnicy. A w końcu przez wiare Abraham złożył w ofierze swego jedynego syna” (KKK 145); „Powinniśmy wtedy zwrócić się do świadków wiary: Abrahama, który "wbrew nadziei uwierzył nadziei" (Rz 4,18); „Maryi Dziewicy, która w "pielgrzymce wiary” doświadczyła nawet "nocy wiary", uczestnicząc w cierpieniu Syna i nocy Jego grobu; i tylu innych świadków wiary: "Mając dokoła siebie takie mnóstwo świadków, odłożywszy wszelki ciężar, a przede wszystkim grzech, który nas łatwo zwodzi, winniśmy wytrwale biec w wyznaczonych nam zawodach. Patrzmy na Jezusa, który nam w wierze przewodzi i ją wydoskonala" (Hbr 12,1-2) (KKK 165).

19 "Powszedniego". Wyraz ten, w języku greckim epioúsios, nie pojawia się nigdzie więcej w Nowym Testamencie. W znaczeniu czasowym jest to pedagogiczne powtórzenie owego „dzisiaj” dla utwierdzenia w nas ufności „bez zastrzeżeń. W znaczeniu jakościowym oznacza to, co jest konieczne do życia, a mówiąc szerzej: wszelkie dobro wystarczające do utrzymania. Dosłownie (epioúsios: nad-zwyczajny) oznacza wprost Chleb Życia, Ciało Chrystusa, «lekarstwo nieśmiertelności”, bez którego nie mamy w sobie Życia. Wreszcie, znaczenie to w powiązaniu z poprzednim - dotyczy w sposób oczywisty nieba: "Powszedni» znaczy "należący do dnia Pańskiego", dnia Uczty w Królestwie, uprzedzanej w Eucharystii, która jest przedsmakiem nadchodzącego Królestwa. Dlatego 
otrzymuje już przedsmak tego, co czeka na niego u celu jego pielgrzymki ${ }^{20}$. Także inne sakramenty stają się pomocą na pielgrzymiej drodze ${ }^{21}, \mathrm{czy}$ to w samym byciu w tejże ziemskiej drodze czy jako pokarm w ostatnim jej etapie - w przejściu do Wieczności. Same w sobie pełne są pielgrzymich symboli.

liturgia eucharystyczna powinna być celebrowana "codziennie". Eucharystia jest naszym chlebem codziennym. Zaletą tego Bożego pokarmu jest siła jedności: jednoczy nas z Ciałem Zbawiciela i czyni nas Jego członkami, abyśmy mogli stać się tym, co przyjmujemy... Ten chleb powszedni znajduje się też w czytaniach, których słuchamy każdego dnia w kościele, w hymnach, które wszyscy śpiewamy. Wszystko to jest niezbędne w naszym ziemskim pielgrzymowaniu. Ojciec niebieski zachęca nas, abyśmy jako dzieci nieba prosili o Chleb z nieba. Chrystus "sam jest tym chlebem, który - zasiany w Dziewicy, wyrosły w ciele, ukształtowany $\mathrm{w}$ męce, wypieczony $\mathrm{w}$ piecu grobu, przechowywany w Kościele, przynoszony na ołtarze - codziennie udziela wiernym owego niebieskiego pokarmu"" (KKK 2837); "Komunia święta w przedziwny sposób dokonuje w naszym życiu duchowym tego, czego pokarm materialny w życiu cielesnym. Przyjmowanie w Komunii Ciała Chrystusa Zmartwychwstałego, "ożywionego i ożywiającego Duchem Świętym" (DK 5), podtrzymuje, pogłębia i odnawia życie laski otrzymane na chrzcie. Wzrost życia chrześcijańskiego potrzebuje pokarmu Komunii eucharystycznej, Chleba naszej pielgrzymki, aż do chwili śmierci, gdy zostanie nam udzielony jako Wiatyk" (KKK 1392); „Chrystus, przechodząc z tego świata do Ojca, dal nam w Eucharystii zadatek swojej chwały; udział w Najświętszej Ofierze utożsamia nas z Jego Sercem, podtrzymuje nasze siły w czasie ziemskiej pielgrzymki, budzi pragnienie życia wiecznego i już teraz jednoczy nas z Kościołem niebieskim, ze świętą Dziewicą Maryją i wszystkimi świętymi” (KKK 1419).

20 „Pielgrzymujący Lud Boży, nieustannie celebrując Eucharystię, głosząc Misterium Paschalne Jezusa, "aż przyjdzie" (1 Kor 11, 26), zmierza "wąską drogą krzyża" (DM 1) do niebieskiej uczty, gdzie wszyscy wybrani zasiądą przy stole Królestwa” (KKK 1344).

${ }^{21}$ „Chrzest, bierzmowanie i Eucharystia są sakramentami wtajemniczenia chrześcijańskiego. Na nich opiera się wspólne powołanie wszystkich uczniów Chrystusa, powołanie do świętości i do misji ewangelizacji świata. Udzielają one łask koniecznych do życia według Ducha podczas ziemskiej pielgrzymki prowadzącej do Ojczyzny (KKK 1533); Sakrament pokuty jedna nas z Kościołem. Grzech narusza lub zrywa wspólnotę braterską. Sakrament pokuty naprawia ją lub przywraca. W tym sensie nie tylko leczy on powracającego do komunii kościelnej, lecz także ożywia życie Kościoła, który cierpiał z powodu grzechów jednego ze swych członków. (...) Należy też dodać, że owo pojednanie z Bogiem rodzi można powiedzieć - dalsze pojednania, które naprawiają inne rozdarcia spowodowane przez grzech: penitent, który uzyskał przebaczenie, jedna się z samym sobą w głębi własnego ja, odzyskując wewnętrzną prawdę; jedna się z braćmi, w jakiś sposób przezeń skrzywdzonymi i znieważonymi; jedna się z Kościołem, jedna się z całym stworzeniem" (KKK 1469). 
Eklezjologiczna metafora pielgrzymowania rozciąga się szerzej na: pielgrzymujący Kościół jednoczących się wspólnot ${ }^{22}$, konieczność uświęcania tego $K_{\text {Kościoła }}{ }^{23}$, jego istotę misyjną (KKK 850) i ostatecznie jedność Kościoła ${ }^{24}$, który jako pielgrzym jest jeszcze w drodze, ze wspólnotą pielgrzymów, która już dotarła do Świętego Miasta. Kościół jest zatem poniekąd sakramentem dla pielgrzymów w ich ziemskiej drodze, która znajduje swój ostateczny koniec $\mathrm{w}$ momencie śmierci ${ }^{25}$.

22 „Jakie są więzy jedności Kościoła? "Na to. wszystko przyobleczcie miłość, która jest więzią doskonałości» (Kol 3, 14). Jedność Kościoła pielgrzymującego jest zapewniana także przez widzialne więzy komunii: wyznanie jednej wiary otrzymanej od Apostołów; wspólne celebrowanie kultu Bożego, przede wszystkim sakramentów; sukcesję apostolską za pośrednictwem sakramentu święceń, która to sukcesja strzeże braterskiej zgody rodziny Bożej" (KKK 815).

23 „Jak należy rozumieć to stwierdzenie często powtarzane przez Ojców Kościoła? Sformułowane w sposób pozytywny oznacza, że całe zbawienie pochodzi jedynie od Chrystusa-Głowy przez Kościól, który jest Jego Ciałem: Sobór święty opierając się na Piśmie świętym i Tradycji, uczy, że ten pielgrzymujący Kościół konieczny jest do zbawienia. Chrystus bowiem jest jedynym Pośrednikiem i drogą zbawienia, On, co staje się dla nas obecny w Ciele swoim, którym jest Kościół; On to właśnie podkreślając wyraźnie konieczność wiary i chrztu, potwierdził równocześnie konieczność Kościoła, do którego ludzie dostają się przez chrzest jak przez bramę. Nie mogliby więc zostać zbawieni ludzie, którzy wiedząc, że Kościół założony został przez Boga za pośrednictwem Chrystusa jako konieczny, mimo to nie chcieliby bądź przystąpić do niego, bądź też w nim wytrwać" (KKK 846).

24 „Trzy stany w Kościele. "Dopóki Pan nie przyjdzie w majestacie swoim, a wraz z Nim wszyscy aniołowie, dopóki po zniszczeniu śmierci wszystko nie zostanie $\mathrm{Mu}$ poddane, jedni spośród Jego uczniów pielgrzymują na ziemi, inni, dokonawszy żywota, poddają się oczyszczeniu, jeszcze inni zażywają chwały, widząc wyraźnie samego Boga troistego i jedynego, jako jest” (KK 49).Wszyscy jednak, w różnym stopniu i w rozmaity sposób, złączeni jesteśmy wzajemnie w tej samej miłości Boga i bliźniego i ten sam hymn chwały śpiewamy Bogu naszemu. Wszyscy bowiem, którzy należą do Chrystusa, mając Jego Ducha, zrastają się w jeden Kościół i zespalają się wzajemnie ze sobą w Chrystusie" (KKK 954).

25 „Chrześcijańska wizja śmierci jest wyrażona szczególnie trafnie w liturgii Kościoła: Albowiem życie Twoich wiernych, o Panie, zmienia się, ale się nie kończy, i gdy rozpadnie się dom doczesnej pielgrzymki, znajdą przygotowane w niebie wieczne mieszkanie” (KKK 1012); „Śmierć jest końcem ziemskiej pielgrzymki człowieka, czasu łaski i miłosierdzia, jaki Bóg ofiaruje człowiekowi, by realizował swoje ziemskie życie według zamysłu Bożego i by decydował o swoim ostatecznym przeznaczeniu. Gdy zakończy się "jeden jedyny bieg naszego ziemskiego żywota" (KK 48), nie wrócimy już do kolejnego życia ziemskiego. "Postanowione ludziom raz umrzeć" (Hbr 9, 27). Po śmierci nie ma "reinkarnacji»" (KKK 1013). 
Podsumowując dotychczasowe analizy, można stwierdzić, że wypowiedzi Katechizmu Kościoła Katolickiego na temat pielgrzymowania i pielgrzymów ida zasadniczo po linii krytyki, którą znajdujemy w teologii Ojców Kościoła. Katechizm uznaje, że wprawdzie święte miejsca są pomocne w ćwiczeniach duchowych i mogą służyć pogłębianiu praktyk pobożnościowych, to jednak nie należy zapominać, że decydujące znaczenie dla gromadzenia wiernych mają lokalne Kościoły, i to zarówno gdy idzie o kult publiczny, jak i o prywatną modlitwę.

Podobnie jak u św. Augustyna, który opisał chrześcijańską egzystencję jako pielgrzymowanie, w Katechizmie rozumiana jest wiara - jako pielgrzymowanie do Boga. Także i Kościół pojmowany jest jako pielgrzymująca wspólnota wierzących, która jako uniwersalne zgromadzenie duchowo jest w drodze ku Chrystusowi. W tym miejscu należy dodać, że pojęcie duchowej pielgrzymki, wewnętrznego bycia w drodze ku Chrystusowi, ku prawdziwej świątyni i ku niebieskiemu Jeruzalem, zarówno w odniesieniu do indywidualnego wierzącego, jak i do całego Kościoła pojmowanego jako pielgrzymujący Lud Boży, należy do chrześcijańskiego proprium. W latach 70. XX w. Joseph Ratzinger wskazał na chrystologiczny grunt tej wewnętrznej pielgrzymki: „(...) istotą drogi chrześcijańskiej jest zespolenie własnej woli z wolą Boga" (Ratzinger 2007: 256)26. To wewnętrzne bycie w drodze zmierzające do przyjęcia woli Ojca określił on jako wiarę- wiarę, która jest posłuszna (Ratzinger 2007)27.

Zastanówmy się teraz, jakie konsekwencje dla duszpasterstwa pielgrzymkowego wynikają w związku z dynamicznym wzrostem ruchu pątniczego oraz przesuwaniem akcentu $\mathrm{z}$ pielgrzymowania grupowego ku indywidualnemu wędrowaniu do świętych miejsc.

26 J. Ratzinger w prawie niedostrzegalny sposób wprowadził do swej teologicznej rozprawy kwestię duchowego bycia w drodze i duchowego pielgrzymowania. Wątek ten pojawia się także w jego wypowiedziach jako papieża, znajdując tam swoją kontynuację i rozwój. Wyciska tam swoje wyraźne piętno. Sprawa ta jednak wymagałaby odrębnego studium.

27 Tamże, s. 256; podobną myśl można znaleźć u Sean Freyne, 1996, Jesus der Pilger, "Concilium”, 32, s. 315-321, tu s. 319-320, ów wątek nie jest wykorzystany dokładnie tak jak u Ratzingera - w odniesieniu do Getsemani - lecz w kontekście arcykapłańskiej modlitwy Jezusa: Jego prawdziwa pielgrzymka prowadzi nie do Jeruzalem, dokad on wcześniej pielgrzymowat ( $J 6,62 ; 7,1-10)$. To pielgrzymowanie osiagga swój punkt szczytowy w ostatniej modlitwie Jezusa (J 17), duchowa podróż do Boga jako poprzedzenie jego śmierci, przedstawiana jest tutaj jako uwielbienie. 


\section{Konsekwencje pastoralne}

Główne pytanie w związku z problemem osób będących w drodze do świętych miejsc, na podstawie wyżej scharakteryzowanego chrześcijańskiego proprium odnoszącego się do kwestii pielgrzymowania, można sformułować następująco: Czy droga pielgrzymkowa pozwala na wejście w głębię Ewangelii (Wecker 2011). Innymi słowy, czy zewnętrzne bycie człowieka w drodze prowadzi go do wewnętrznego pielgrzymowania ku Chrystusowi. Pastoralne towarzyszenie zewnętrznej pielgrzymce powinno wprowadzać w wewnętrzne bycie $w$ drodze. Duszpasterstwo pielgrzymkowe zmierza do transitus - doprowadzenia człowieka do spotkania z Chrystusem. To jest zapewne proces, który sam ma charakter drogi, podobnie jak drogą jest pielgrzymka sama w sobie. Jakie zatem duszpasterskie, praktyczne koncepcje konieczne są tu do przemyślenia?

\subsection{Kształtowanie motywów wyruszania w drogę}

Pierwszym momentem $w$ duszpasterstwie pielgrzymkowym powinno być pytanie o motywy wyruszenia w drogę. Z pomocą duszpasterstwa każdy pielgrzym może podjąć indywidualną refleksję nad osobistymi motywami i wewnętrznie je ugruntować, odnosząc do sytuacji własnego życia. Mogą to być zewnętrzne przyczyny, takie jak: oderwanie się od codzienności, tęsknota, by przynajmniej jeden raz, czy to samotnie czy też w grupie, być w drodze pieszo - jak to było u początków ludzkości, bądź doświadczenie granic wytrzymałości cielesnej. Wyruszeniu w droge mogą towarzyszyć także wewnętrzne motywy, które mają związek z aktualną sytuacją życiową: poszukiwanie sensu lub kryzys sensu, pragnienie odnalezienia siebie, nowy początek po jakimś zawodowym lub prywatnym rozczarowaniu, życiowy przełom po zakończeniu pewnego etapu życia, bądź rozpoczęcie czegoś zupełnie nowego. Możliwe, że pojawią się także motywy religijne: prośba o wysłuchanie w jakiejś fizycznej lub duchowej potrzebie, ugruntowanie w dokonaniu ważnego, życiowego wyboru, być może podziękowanie za wysłuchanie w modlitwie, które to pielgrzymujący wiążą z określonym miejscem. Ten, kto określa się jako pielgrzym, jest zatem w drodze do świętego miejsca z bardzo różnorodnych motywów. Otwierają go one na duszpasterskie propozycje i skłaniają do osobistej refleksji. 


\subsection{Odkrycie świętego ośrodka jako miejsca bliskości Chrystusa}

Sacrum miejsca przyciąga człowieka. Pozwala mu przemierzyć drogę wraz ze swoimi cielesnymi, jak i egzystencjalnymi obciążeniami. Owo sacrum poprzez ukształtowanie zewnętrznych, wewnętrznych oraz religijnych motywów służy uczynieniu następnego kroku, jakim jest odkrycie bliskości Chrystusa.

Może się zdarzyć, że na początku towarzyszą pielgrzymowi zupełnie zewnętrzne motywy, dla których decyduje się on na wyruszenie w drogę do tego czy innego sanktuarium. Jednak po pewnym czasie pojawiają się głębsze pytania o sens tej wędrówki. Wówczas, z pastoralnego punktu widzenia, otwiera się przestrzeń do pogłębienia motywacji pielgrzyma, który pyta: co decyduje o sacrum wybranego miejsca? Skąd pochodzi jego siła przyciągania? Co było decydujące przy wyborze tego miejsca? Możliwe, że pielgrzym nie zdoła odpowiedzieć sobie na pytanie, dlaczego jego wybór padł na to a nie na inne sanktuarium. Być może sacrum tego miejsca przesłonięte jest innymi motywami, na przykład popularnością określonych dróg pielgrzymkowych (np. Droga św. Jakuba do Santiago de Compostela) lub rozpowszechnioną tradycją pielgrzymkową (Mariazell jako narodowe sanktuarium Austrii jest również miejscem ludowej identyfikacji, a dodatkowo było faworyzowane przez cesarzową Marię Teresę - do tego stopnia, że inne pielgrzymki, np. do Santiago były zabronione).

Uwrażliwienia na sacrum danego miejsca najlepiej da się dokonać poprzez nawiązanie do historii chrześcijańskich pielgrzymek. Bo to właśnie owe święte miejsca chrześcijaństwa były zawsze ośrodkami przeżywania bliskości z Chrystusem. Pierwsi chrześcijańscy pielgrzymi wyruszali do historycznych miejsc, w których żył Jezus, gdzie cierpiał, umarł i zmartwychwstał. Pragnęli znaleźć się bliżej Chrystusa poprzez styczność z miejscami, które dotknęło Jego historyczne ciało. W tym samym czasie przybywali do ośrodków pielgrzymkowych Ziemi Świętej, szczególnie do grobów męczenników, którzy żyli w bliskości z Chrystusem (Pasquato 1989). Przy tychże grobach, wokół których ukształtował się pielgrzymkowy kult, spodziewali się dotknięcia Chrystusa w osobach Jego świadków, u których oczekiwali opieki, wstawiennictwa i obrony ${ }^{28}$. W tym kontekście staje się zrozumiałym paradoks, że

${ }^{28}$ Podobnie jest także w powstałych później miejscach pielgrzymkowych związanych z Maryją czy też świętymi nie będącymi męczennikami bądź w wypadku przestrzeni odwzorowujących miejsca świete, jak np. kalwarie. 
miejscami świętymi, a tym samym pielgrzymkowymi, stawały się miejsca zagłady i poniżenia człowieka, bo to właśnie w nich dla Chrystusa cierpieli i przelewali swoją krew męczennicy. Znamienitym przykładem jest tutaj papież Jan Paweł II, który podczas swej wizyty w Auschwitz nazwał siebie pielgrzymem (Johannes Paul II 1979). Jako pielgrzym nawiedził on miejsce szczególnego okrucieństwa, jakim była cela śmierci św. męczennika. Modlił się w niej św. Maksymilian Kolbe, ogarnięty miłością bliźniego, zakorzenioną w Chrystusie. Jego miłość do Chrystusa stała się dla współwięźniów świadectwem dającym światło i nadzieję w nocy śmierci.

Przy grobach męczenników - by jeszcze raz przywołać ten typ pielgrzymowania - duża rola przypada duszpasterskiej opiece nad pielgrzymami. Jej zadaniem jest wzbudzenie w pielgrzymach pragnienia naśladowania tych świadków wiary, by ich śladem wędrować za Chrystusem. Jako unaocznienie świadectwa ich życia mogą posłużyć różne formy wizualnego przedstawienia ich postaci. Dobrze postrzeganymi mediami są: tablice informacyjne, broszurki, foldery, nagrania wideo, wystawy, ale także różnego rodzaju artystyczne prezentacje, dzięki którym pielgrzymi mogą lepiej zapoznać z życiem męczennika i związanym z nim miejscem. Rzeczone medialne prezentacje wychodzą od locus sacer, dyskretnie próbują wzbudzić zainteresowanie tajemnicą tego świętego miejsca i przybliżyć jego głębszy wymiar. Taką rolę zbliżania do sacrum nawiedzanego ośrodka może pełnić odpowiednio przygotowane oprowadzanie po świętym miejscu i jego okolicy. Mianowicie oprowadzanie mające charakter mistagogiczny (wtajemniczający). We wszystkich tego typu formach duszpasterskiego oddziaływania otwiera się szerzej szansa zbliżania pielgrzyma do Chrystusa. Opieka nad pielgrzymem ma się realizować poprzez rozmaite formy duszpasterstwa: duszpasterstwo indywidualne, wspólną liturgię sprawowaną w świętym miejscu oraz inne formy pielgrzymkowych nabożeństw.

\subsection{Transitus - przejście od zewnętrznej drogi do wewnętrznego spotkania z Chrystusem}

Już u Jana Chryzostoma, jak uważa Ottorino Pasquato (1989), odnaleźć można stwierdzenie, że psychologia pielgrzymki przedstawia się jako rodzaj terapii za pomoca przestrzeni (therapia mediante lo spacjo) ${ }^{29}$. Przez bycie w drodze do

${ }^{29}$ Por. tutaj rezultat studiów nad pielgrzymowaniem w pismach Jana Chryzostoma, Problemi degli sposamenti, s. 122. 
miejsca świętego pielgrzym uwalnia się od przeszłości i otwiera się na nowość przyszłości. Jednak prawdziwa pielgrzymka realizuje się tam, gdzie przez zewnętrzne pielgrzymowanie otwiera się wnętrze, czyli dokonuje się nawrócenie serca. Prawdziwym miejscem świętym jest sam Jezus Chrystus, ku któremu zmierzają wszyscy chrześcijańscy pielgrzymi. Aby uskutecznić wspomniane egzystencjalne przejście od zewnętrznej drogi do duchowego spotkania z Chrystusem, duszpasterstwo powinno podejmować odpowiednie kroki, tworząc sprzyjające warunki do tegoż spotkania. Także tutaj są możliwe różnorodne formy duszpasterskich działań, od przygodnych spotkań, otwartych kręgów dyskusyjnych, aż po specyficzne duszpasterskie rozmowy oraz sakramentalną spowiedź - w formie indywidualnej, anonimowej bądź też w formie rozmowy połączonej z kierownictwem duchowym, w szczególności spowiedź generalną, która umożliwi nowy początek życia ${ }^{30}$. Słusznie sądzi Kurt Joseph Wecker (2011: 272), który nazywa duszpasterzy opiekujących się pielgrzymami interpretatorami, pośrednikami i świadkami, którzy „pomagają poszukującym porządkować ich niekiedy pokomplikowane drogi życia i żyć autentycznie naśladując Jezusa. Aby zatem (...) pielgrzymia droga niespodziewanie nie przerodziła się w zwykłe zwiedzanie, wymaga duchowego towarzyszenia. Bez kompetentnego przewodnika (interpretatora) zwiedzający stoją ślepi w miejscach świętych i zostaną nakarmieni wyłącznie archeologiczno-historycznymi informacjami, pozostaną oniemiali i nie poruszeni charyzmatem nawiedzanego miejsca. Bez przygotowania owego „gruntu rezonansu” [„Resonanzbodens”], bez mistagogii (wtajemniczenia) niektórzy pielgrzymi pozostaną jak ślepi poruszający się po omacku. Zostaną utwierdzeni w tym, co już wiedzą (bez wspomnianego wtajemniczenia). Będą widzieli tylko zewnętrzne obiekty. Droga pielgrzymkowa powinna być drogą inicjacji, podróżą formacji: "Chrystus i święci chcą się mi dać wyobrazić. Pobożny pielgrzym poszukający mnie (Chrystusa, Świętego) powinien odnaleźć okazję aby móc wejść w moje wnętrze" (Wecker 2011: 272).

Zjednoczenie z Chrystusem znajduje swój punkt kulminacyjny we wspólnym celebrowaniu Eucharystii przez pielgrzymów, podczas której wspominane wcześniej przejście (transitus) zostaje urzeczywistnione i doświadczone w sakramentalny

${ }^{30}$ Do pastoralnych pomocy, które pomagają osobiście doświadczyć Chrystusa w miejscu świetym należą przede wszystkim odpowiednie kazania i nabożeństwa pielgrzymkowe, które uwzględniają także pielgrzymów z różnych krajów i sprawowane są w językach obcych. 
sposób. W pielgrzymie, poprzez przyjęcie sakramentu Eucharystii, kształtuje się wyobrażenie Chrystusa. Z drugiej strony pielgrzym pozwala kształtować się Chrystusowi. Gdy w pielgrzymie budzi się wrażliwość do przejścia od zewnętrznego do wewnętrznego wymiaru pielgrzymki - który ciągle posiada eschatologiczny charakter - moment eucharystycznego spotkania z Chrystusem w świętym miejscu staje się czasem kosztowania już teraz wejścia do Świętego Miasta. W ten sposób całe życie pielgrzyma nabiera nowego ukierunkowania, ku doświadczaniu życia jako duchowej pielgrzymki, która jest stałym odwzorowywaniem w sobie Chrystusa.

W tym miejscu należałoby zaakcentować, że wspomniany transitus wymaga wspólnego działania: boskiej inicjatywy i ludzkiej reakcji, boskiego zapytania i ludzkiej odpowiedzi. Dlatego przejście z zewnętrznej do wewnętrznej pielgrzymki jawi się jako wydarzenie majace charakter dialogicznego objawienia. Wychodzi ono bowiem nie tylko jednostronnie od Boga. W pełnym znaczeniu tego terminu, objawienie urzeczywistnia się, gdy słowo Boga spotyka się z gotowością słuchania i odpowiedzi ze strony człowieka ${ }^{31}$.

Zapytajmy teraz co dzieje się w wypadku wielu ochrzczonych, którzy nie udaja się w drogę do świętych miejsc? Co dzieje się z tymi, którzy po pielgrzymce powracają do swojej zwykłej codzienności?

\subsection{Wewnętrzna pielgrzymka. Duszpasterstwo pielgrzymkowe dla pozostających $w$ domach i dla powracających $\mathrm{z}$ pielgrzymek}

Stale rosnąca liczba osób udających się na pielgrzymki oraz duże zainteresowanie ruchem pielgrzymkowym odczuwane są jako swoisty znak czasu. Owa sytuacja pozwala odnieść się także do tych, którzy fizycznie nie wyruszyli na pielgrzymki i są tylko pielgrzymami w wierze, czyli którzy pozostają w domu lub wrócili już $z$ drogi pielgrzymkowej. W codziennym nauczaniu Kościoła warto wykorzystać doświadczenia nabyte podczas pielgrzymek, chociażby uświadomić każdemu ochrzczonemu pielgrzymi charakteru jego życia. W tym celu można posłużyć

$\overline{31}$ Por. dialogiczna struktura objawienia, co zostało na nowo zaakcentowane w soborowej konstytucji Dei Verbum. J. Ratzinger, Einleitung und Kommentar zum Proeomium, rozdz. I, Die Offenbarung, rozdz. II, Die Weitergabe der göttlichen Offenbarung, rozdz. VI, Die Heilige Schrift im Leben der Kirche der Dogmatischen Konstitution über die göttliche Offenbarung, [w:] 2LThK. Ergänzungsband II, 1957-1968, s. $498,503,504-528,571-581$. 
się bardzo różnymi schematami myślowymi, np. wspólnego bycia w drodze wiary ku Chrystusowi, wspólnego wędrowania w wierze małżonków i rodzin, ukazywania, że u podstaw poświęcenia się Bogu w życiu konsekrowanym leży specyficzne przekonanie bycia w drodze ku Chrystusowi, wreszcie przekonywanie osób, które ze względu na cielesne słabości bądź choroby nie mogą fizycznie udawać się w podróż o tym, że i one są w drodze do Świętego Miasta Jeruzalem. Benedykt XVI w swoim przemówieniu z okazji święta Ofiarowania Pańskiego objaśniał „symboliczną pielgrzymkę” (Benedikt XVI 2013: 7) odbywaną w Roku Wiary, wskazując na jej szczególny aspekt - duchową pielgrzymkę realizowaną przez osoby konsekrowane. Powiedział wówczas: „(...) zapraszam was, abyście w tej wewnętrznej pielgrzymce pomyśleli o pierwszej miłości, którą Pan Jezus Chrystus rozgrzał wasze serca. Niech nie będzie ona dla was nostalgią ale przełomem, który rozpali was na nowo" (Benedikt XVI 2013: 7).

Stąd wewnętrzne pielgrzymowanie w wierze wskazuje dwojaki kierunek, który da się urzeczywistnić w każdej sytuacji życiowej ludzi różnych stanów. Z jednej strony jest to kierunek dobrze nam już znany, związany z eschatologiczną pielgrzymką ku Chrystusowi. Z drugiej strony jest to wskazana przez Benedykta XVI wewnętrzna pielgrzymka pamięci, która jest wdzięcznym wspomnieniem już zakończonego etapu drogi pielgrzymiej i związanym z tym pełnym nadziei odnowieniem drogi przemierzanej z Chrystusem czy to od czasu chrztu, zawarcia małżeństwa, czy też wstąpienia na szlak życia konsekrowanego. W tej podwójnej strukturze wewnętrznej pielgrzymki, w kontekście wielkiej i małej historii zbawienia człowieka, i przy spojrzeniu ku temu co ma przyjść, ku Chrystusowi, ku celowi historii, dobitniej ujawnia się struktura ludzkiej egzystencji. Metafora pielgrzymki, której celem jest Chrystus nie tylko zostaje zaktualizowana, ale odkrywana jest w całkowicie nowy sposób.

\subsection{Ekumenizm zewnętrznej i wewnętrznej pielgrzymki}

W naszej teologiczno-pastoralnej refleksji na temat chrześcijańskich podstaw pielgrzymowania, w związku z wczesnochrześcijańską i współczesną krytyką, nie może zabraknąć odniesienia do wymiaru ekumenicznego. Przedstawimy tylko fragmentarycznie duszpasterskie wątki związane z tą kwestią. W 2014 r. obchodzono rocznicę spotkania papieża Pawła VI i patriarchy Athenagorasa w Jerozolimie na Górze Oliwnej, gdzie obydwaj jako główni przedstawiciele swoich Kościołów, po wiekach chłodnych stosunków, w środku zimy, braterskim pocałunkiem rozpoczęli 
wiosnę ekumenicznych relacji. Papież przybył jako pielgrzym. Chciał pielgrzymować do świętej ziemi Jezusa, będącej świadkiem Jego życia i właśnie tam modlić się o jedność chrześcijan. To wydarzenie z pewnością nie było li tylko zwiedzaniem miejsc, ale prawdziwą pielgrzymką ${ }^{32}$. Podczas jej trwania, w 1964 r. po raz pierwszy po 700 latach od zakończenia soboru we Florencji, wystąpili wspólnie najwyżsi przedstawiciele Kościoła rzymskokatolickiego i prawosławnego. Spotkanie odbyło się w miejscu, gdzie sam Jezus w zmagał się w modlitwie o poddanie woli Ojca (por. Mk 14,36). Zeszli się razem na Górze Oliwnej, w miejscu duchowej męki Jezusa, gdzie jego zewnętrzna pielgrzymka do Jerozolimy osiągnęła swój kres. To była wewnętrzna wędrówka ku jedności z wolą Ojca - jak to sformułował J. Ratzinger. W pewnym stopniu wybór Góry Oliwnej przez obydwu Pielgrzymów miał swoje głębokie teologicznie znaczenie. Zebrali się bowiem tam, gdzie Jezus szedł przed nimi w swojej duchowej pielgrzymce ku poddaniu w wierze swemu Ojcu, które stanowi fundament wszelkiej prawdziwej jedności.

Chociaż w dalszym ciągu katolickie i prawosławne szlaki pielgrzymkowe biegną osobno ${ }^{33}$, to jednak wspomnienie braterskiego pocałunku dwóch wielkich Pielgrzymów na Górze Oliwnej sprzed 50. lat stanowi impuls do tego, by pielgrzymi z Zachodu i Wschodu razem wyruszyli w droge, zewnętrznie, ale jeszcze bardziej wewnętrznie, by ich wspólne zmierzanie do świętych miejsc i wspólna wiara w Chrystusa stały się wobec świata świadectwem jedności chrześcijan. Ekumeniczne duszpasterstwo pielgrzymkowe jak dotąd nie zostało odkryte, ale stanowi pełną nadziei gałąź pastoralnej troski o osoby znajdujące się w drodze do świętych miejsc.

Tłumaczenie z j. niemieckiego: ks. Maciej Ostrowski, ks. Michał Wilkosz.

32 Consentaneum igitur erat - idque ex providentis Dei consilio reapse accidit ut hoc ipso loco, in hac praecipua terrarum orbis parte, in perpetuum sacra ac veneranda, liceret nobis, Roma et Constantinopoli pie peregrinantibus, invicem obviam ire et communes sup plicationes consociare (Paul VI., 1964, Allocutio ad exc. Mum d. Athenagoras, Patriarcha Oecumenicum Constantinopolitanum [5. Januar], AAS”, 56, s. 171-173, tutaj 172-172.

${ }^{33}$ Wyjątkiem jest tutaj die Heilig-Rock-Walllfahrt do Trewiru w 2012 r., gdzie pielgrzymowali katolicy i prawosławni, aby zjednoczyć się $\mathrm{w}$ modlitwie przy niepodzielonej szacie Jezusa. Pastoralnym mottem tego spotkaniaa było: zjednocz razem, to co jest rozdzielone. Pielgrzymkowa modlitwa w Trewirze brzmiała: Jezu Chryste Zbawco i Odkupicielu, zmiłuj się nad nami i nad całym światem. Wejrzyj na chrześcijan i zjednocz to co jest rozdzielone. Amen (Gebetsbildchen zum Andenken an die Heilig-Rock-Wallfahrt Trier, 13. April bis 13. Mai 2012). 


\section{Literatura}

Augustinus, 1917, Des heiligen Kirchenvaters Augustinus ausgewählte Briefe, hrsg. und übersetzt von O. Badenhewer u.a., Kempten-München (Bibliothek der Kirchenväter 30).

Augustinus, 1914, Des heiligen Kirchenvaters Aurelius Augustinus Bekenntnisse, aus dem Lateinischen übersetzt von Dr. Alfred Hofmann, München (Bibliothek der Kirchenväter I/18).

Augustinus, 1916, Des heiligen Kirchenvaters Aurelius Augustinus zweiundzwanzig Bücher über den Gottesstaat, aus dem Lateinischen übersetzt von A. Schröder, Kempten-München (Bibliothek der Kirchenväter I/28).

Augustinus, 1925, Enchiridion, d.h. Handbüchlein für den Laurentius oder Buch vom Glauben, von der Hoffnung und von der Liebe, [w:] Des heiligen Kirchenvaters Aurelius Augustinus ausgewählte Schriften. Aus dem Lateinischen übersetzt, Kempten-München, s. 291-502 (Bibliothek der Kirchenväter I/49).

Augustyn, 1987, Wyznania, Instytut Wydawniczy PAX, Warszawa.

Benedikt XVI, 2013, Schönheit und Wert des geweihten Lebens als Wiederschein des Lichtes Christi. Predigt am 2, „L'Osservatore Romano” (deutsch), nr. 7 (15.02.), s. 7. Danielou J., 1950, Sacramentum futuris, Paris.

Egeria, 1995, Itinerarium. Reisebericht. Mit Auszügen aus Petrus Diaconus' De locis sanctis, Die Heiligen Stätten. Lateinisch-Deutsch, Freiburg i. Br. („Fontes Christianae" I/20).

Eusebius von Caesarea, 1932, Des Eusebius Pamphili Bischof von Caesarea Kirchengeschichte, aus dem Griechischen übersetzt von P. Haeuser, München („Bibliothek der Kirchenväter" II/1).

Franziskus, 2014, Dem Evangelium dienen und der Kirche helfen, „L'Osservatore Romano" (Deutsche Auflage), nr 9 (28.02.), s. 1.

Freyne S., 1996, Jesus der Pilger, „Concilium”, 32, s. 315-321.

Jan Paweł II, 2012, Konstytucja Apostolska Fidei depositum, [w:] Katechizm Kościoła katolickiego, Pallotinum, Poznań, s. 10-14.

Johannes Paul II., 1979, Predigt im Konzentrationslager Auschwitz (Birkenau) (7. Juni 1979), „L'Osservatore Romano” (deutsch), nr 25, s. 1.

Katechizm Kościoła Katolickiego, 2012, Pallotinum, Poznań.

Kempis T., 1980, O naśladowaniu Chrystusa, Instytut Wydawniczy PAX, Warszawa.

Koran, 1986, tłum. J. Bielawski, PIW, Warszawa. 
Kötting B., 1950, Peregrinatio religiosa. Wallfahrten in der Antike und das Pilgerwesen in der alten Kirche, Regensburg, Münster.

Kötting B., 1962, Gregor von Nyssa's Wallfahrtskritik, „Studia Patristica”, 5 [Texte und Untersuchungen zur Geschichte der altchristlichen Literatur 80], s. 360-367.

Manns F., 1989, Il giudeo-christianesimo e il fenomeno della mobilitá, [w:] Pontificium Consilium de Spirituali Migrantium atque Itinerantium Cura, L'epoca patristica e la pastorale della mobilitá umana „Senza Frontiere. Serie Teologico-Pastorale”), Edizioni Messagero Padova, s. 15-53.

Müller G. L.,1995, Katholische Dogmatik. Für Studium und Praxis der Theologie, Freiburg-Basel-Wien.

Pasquali G., 1959, Gregorii Nysseni Epistolae, Herausgegeben von Werner Jaeger, Leyden.

Pasquato O., 1989, Il problema degli spostamenti die popoli negli scritti di Giovanni Chrisostomo, [w:] Pontificium Consilium de Spirituali Migrantium atque Itinerantium Cura, L'epoca patristica e la pastorale della mobilitá umana („Senza Frontiere. Serie Teologico-Pastorale"), Edizioni Messagero Padova, s. 89-123.

Paul VI., 1964, Allocutio ad exc. Mum d. Athenagoras, Patriarcha Oecumenicum Constantinopolitanum [5. Januar 1964], „Acta Apostolicae Sedis”, 56, s. 171-173.

Ratzinger J., Einleitung und Kommentar zum Proeomium, rozdz. I, Die Offenbarung, rozdz. II, Die Weitergabe der göttlichen Offenbarung, rozdz. VI, Die Heilige Schrift im Leben der Kirche der Dogmatischen Konstitution über die göttliche Offenbarung, [w:] 2LThK. Ergänzungsband II, 1957-1968, s. 498, 503, 504-528, 571-581.

Ratzinger J., 2007, Gottes Macht - unsere Hoffnung. Vortrag im Rahmen des Dresdener Katholikentreffens 1987, [w:] Benedikt XVI., Priester aus innerstem Herzen. Beiträge im Klerusblatt aus fünf Jahrzehnten, im Auftrag des Klerusverbandes herausgegeben von F. Trenner, München, s. 246-264.

Ratzinger J., 1992, Volk und Haus Gottes in Augustins Lehre von der Kirche [1951], EOS Verlag, St. Ottilien (Münchener Theologische Studien. Systematische Abteilung, 7).

Ratzinger J., 1963, Wesen und Grenzen der Kirche, [w:] K. Forster (red.), Das Zweite Vatikanische Konzil, Würzburg, s. 47-68 („Studien und Berichte der Katholischen AkademieBayern", 24), tożsame Der Kirchenbegriff und die Frage nach der Gliedschaft in der Kirche, [w:] Joseph Ratzinger, 2010, Gesammelte Schriften 8/1, s. 290-307. 
Rigi C., 1989, Antropologia del pellegrinaggio religiose nei primi secoli, [w:] Pontificium Consilium de Spirituali Migrantium atque Itinerantium Cura, L'Epoca Patristica e la Pastorale della mobilitá umana, („Senza Frontiere. Serie Teologico Pastorale”), s. $124-148$.

Wecker K. J., 2011, Pilgern, Tourismus, Pilgertourismus. Eine kleine Phänomenologie des bewegten Glaubens, „Pastoralblatt”, 63, s. 267-273.

Michaela C. Hastetter, dr hab.

Privatdozentin $w$ Albert-Ludwigs-Universität we Freiburgu Bryzgowijskim (Niemcy), profesor wizytujący $w$ Międzynarodowym Inst. Teologicznym $w$ Trumau (Austria) oraz Wyższej Szkole Filozoficzno-Teologicznej Benedykta XVI w Heiligenkreuz (Austria) 
